\title{
Anaerobic co-digestion of macroalgal biomass with cattle manure under high salinity conditions
}

Tsapekos, Panagiotis; Kougias, Panagiotis; Alvarado-Morales, Merlin; Raga, R.; Angelidaki, Irini

Publication date:

2018

Document Version

Peer reviewed version

Link back to DTU Orbit

Citation (APA):

Tsapekos, P., Kougias, P., Alvarado-Morales, M., Raga, R., \& Angelidaki, I. (2018). Anaerobic co-digestion of macroalgal biomass with cattle manure under high salinity conditions. Abstract from Biogas Science 2018, Torino, Italy.

\section{General rights}

Copyright and moral rights for the publications made accessible in the public portal are retained by the authors and/or other copyright owners and it is a condition of accessing publications that users recognise and abide by the legal requirements associated with these rights.

- Users may download and print one copy of any publication from the public portal for the purpose of private study or research.

- You may not further distribute the material or use it for any profit-making activity or commercial gain

- You may freely distribute the URL identifying the publication in the public portal 


\title{
ANAEROBIC CO-DIGESTION OF MACROALGAL BIOMASS WITH CATTLE MANURE UNDER HIGH SALINITY CONDITIONS
}

\author{
Tsapekos, P. ${ }^{1}$, Kougias, P. ${ }^{1}$, Rudatis, A. ${ }^{1,2}$, Alvarado-Morales, M. ${ }^{1}$, Raga, R. ${ }^{2}$, Angelidaki, I. ${ }^{1}$ \\ ${ }^{1}$ Technical University of Denmark, Environmental Engineering, Kgs. Lyngby DK-2800, Denmark \\ ${ }^{2}$ University of Padova, Department of Industrial engineering, via Marzolo $n$ 9, 35131 Padova, Italy \\ e-mail of the corresponding author: ptsa@env.dtu.dk
}

Keywords: Co-digestion; methane; macroalgae; salinity; inhibition

\section{INTRODUCTION}

Animal manures are widely used as feedstock of anaerobic digestion (AD) plants. However, the feasibility of manure-based $\mathrm{AD}$ reactors is challenging due to the low volumetric methane production. In addition, high amount of lignin rich residues are present in the animal slurries that markedly limit the bioenergy output. Hence, there is an imperative need to find high energy-dense substrates that have also increased anaerobic biodegradability to boost the volumetric biogas production of $\mathrm{AD}$ plants. On this topic, terrestrial crops containing high carbohydrates content have been widely examined during the last decades. Despite the high biogas output of energy crops, these cellulosic biomasses compete with conventional agriculture for land exploitation. Thus, sugar rich substrates that do not compete with land usage are of high interest. On this topic, marine biomass can contribute on the hunt for finding substrates to be co-digested with diluted animal slurries. Specifically, macroalgal biomass can be a potential candidate due to increased carbohydrates content and the absence of lignin molecules. In contrast with the promising organic composition, important obstacles are faced using macroalgal biomass for biogas production. The most common problem of marinebased $\mathrm{AD}$ is derived from the high salt concentrations. For instance, sodium and also, potassium are present in high concentration in macroalgal biomass and both of them are known to be inhibitors to AD process. Thus, with respect to anaerobic co-digestion (AcoD) aspects, the inhibition effect of the specific cations should be carefully investigated before macroalgal biomass is used in high-scale AD processes. Overall, the objective of the present study was to evaluate the co-digestion of cattle manure with macroalgal biomass. AcoD with Laminaria digitata was initially examined in batch tests. Subsequently, mono- and co-digestion tests were conducted in replicate continuous mode reactors. Non-acclimatized inoculum to marine biomass was used for all $\mathrm{AD}$ tests. Furthermore, the tolerance thresholds of $\mathrm{AcoD}$ process on relatively high salinity levels were defined and specifically, the sodium concentration that inhibits by $50 \%$ (i.e. $\mathrm{IC}_{50}$ ) the methanation process was revealed. In this context, the results of different salinity levels on the AD process were examined using two different sodium sources (i.e. sodium chloride and marine salt) at six concentrations (i.e. $0.2-12 \mathrm{~g}-\mathrm{Na} / \mathrm{L}$ ).

\section{MATERIALS AND METHODS}

The standard methods for the examination of water and wastewater were followed for substrates characterization and biochemical parameters monitoring (APHA, 2005). Batch and continuous mode experiments were conducted at thermophilic conditions according to the guidelines of the biomethane potential (BMP) protocol (Angelidaki et al., 2009). The $\mathrm{IC}_{50}$ was calculated fitting the experimental results with the Hill model. One way analysis of variance followed by Fisher's Least Significant Difference test $(\mathrm{p}<0.05)$ was used to determine statistically significant differences among samples.

\section{RESULTS AND DISCUSSION}

The results obtained from the present study revealed that the methane yield of L. digitata (>400 $\left.\mathrm{mLCH}_{4} / \mathrm{gVS}\right)$ was significantly higher $(\mathrm{p}<0.05)$ than the value obtained from the mono-digestion of cattle manure $\left(<300 \mathrm{mLCH}_{4} / \mathrm{gVS}\right)$. In addition, no inhibition was detected by the addition of pure saline biomass in 
batch mode experiments. Furthermore, two sets of sodium toxicity tests were conducted to define the sodium inhibition thresholds on methane yield. The $\mathrm{IC}_{50}$ using sodium chloride was found to be $9.0 \mathrm{~g}-\mathrm{Na} / \mathrm{L}$. The obtained result is in accordance with previous literature findings examining cation toxicity on AD process (Onodera et al., 2013). On the contrary, a markedly lower inhibition threshold was revealed for marine salt. Specifically, less than $3.0 \mathrm{~g}-\mathrm{Na} / \mathrm{L}$ were enough to strongly inhibit the AD microbiome. Thus, interaction of sodium with other abundant cations (e.g. magnesium) in the marine salt can be expected, causing a strong inhibitory synergy. Interestingly, the addition of sodium up to $1.0 \mathrm{~g}-\mathrm{Na} / \mathrm{L}$ had a stimulatory effect methane production when sodium chloride was used; as the added light metal ion is required for microbial growth. In contrast, neither positive nor negative statistically different $(p>0.05)$ effect was detected when marine salt was used in the same concentration levels. Monitoring of biochemical parameters during the incubation period of the toxicity batch assays revealed an accumulation of acetate in the inhibited samples. Thus, acetoclastic archaea were probably the most sensitive community on sodium content increment. Regarding the continuous mode operation, the addition of $20 \%$ L. digitata on organic matter basis in the feedstock was examined after the mono-digestion of cattle manure (Fig. 1). As a consequence of feeding with macroalgae, the volumetric biogas production was boosted by $\sim 20 \%$ compared to mono-digestion of cattle manure. Monitoring of biochemical parameters showed total absence of operational problems; such as accumulation of volatile fatty acids, $\mathrm{pH}$ fluctuations, methane content decrease into the biogas etc. Hence, the positive effect of cattle manure AcoD with $L$. digitata was clearly observed also at the continuous mode experiments.

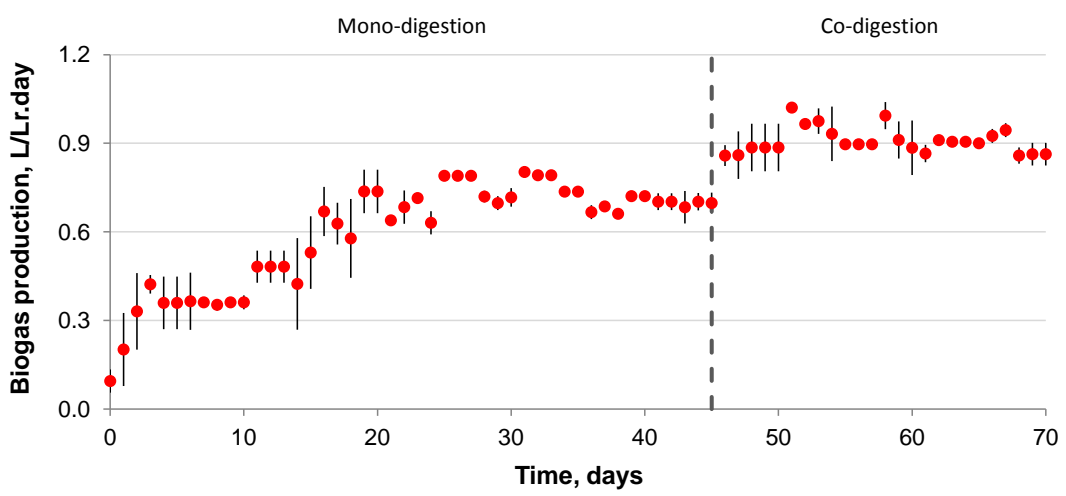

Fig. 1: Volumetric biogas production of mono- and co-digestion of cattle manure with L. digitata

\section{CONCLUSION}

The present study demonstrated that the co-digestion of cattle manure with $L$. digitata was associated with high bioenergy production under batch and continuous mode reactors. No synergistic or antagonistic phenomena were observed under co-digestion experiments. The toxicity tests revealed that inhibitions levels varied based on sodium source. The present findings are important for cases in which marine macroalgae is selected as substrate, using non-acclimatized inoculum to high sodium content.

\section{REFERENCES}

Angelidaki, I., Alves, M., Bolzonella, D., Borzacconi, L., Campos, J.L., Guwy, A.J., Kalyuzhnyi, S., Jenicek, P., van Lier, J.B., 2009. Defining the biomethane potential (BMP) of solid organic wastes and energy crops: a proposed protocol for batch assays. Water Science \& Technology 59, 927.

APHA, 2005. Standard Methods for the Examination of Water and Wastewater. American Public Health Association, Washington, DC, USA.

Onodera, T., Sase, S., Choeisai, P., Yoochatchaval, W., Sumino, H., Yamaguchi, T., Ebie, Y., Xu, K., Tomioka, N., Mizuochi, M., Syutsubo, K., 2013. Development of a treatment system for molasses wastewater: The effects of cation inhibition on the anaerobic degradation process. Bioresource Technology 131, 295-302.

\section{Acknowledgement}

This research was funded by ForskEL Project 12197 "Improving Synergy and Robustness of the Manure CoDigestion Process". 